\title{
РОЗВЕДЕННЯ ЗА ЛІНІЯМИ В РІЗНІ ЕТАПИ ВИВЕДЕННЯ ТА КОНСОЛІДАЦІЇ УКРАЇНСЬКОЇ ЧЕРВОНОЇ МОЛОЧНОЇ ПОРОДИ ВЕЛИКОЇ РОГАТОЇ ХУДОБИ
}

\author{
Підпала Тетяна Василівна \\ доктор с.-г. наук, професор \\ Миколаївський національний аграрний університет, \\ ORCID: https://orcid.org/0000-0002-4072-7576 \\ E-mail: pidpala@mnau.edu.ua \\ Шевчук Наталія Петрівна \\ аспірантка \\ Миколаївський національний аграрний університет \\ ORCID: https://orcid.org/0000-0002-5845-2582 \\ E-mail:shev4uk.n@ukr.net
}

\begin{abstract}
У породоутворювальному процесі розведення за лініями має велике значення для створення структури та закріплення цінної спадковості бажаних генотипів тварин, тому доиільно проаналізувати внутрішньолінійний та міжлінійний підбір на різних етапах виведення та консолідаиії української червоної молочної породи. Для виконання дослідження були використані загальноприйняті зоотехнічні методи (індивідуальний облік молочної продуктивності), лабораторні (визначення якісного складу молока), ретроспективний аналіз (показники за весь період використання тварин), варіаційностатистичний метод (визначення параметрів ознак). Виведення української червоної молочної породи здійснювалося із залученням геносонду англерської, червоної датської та голштинської порід, а тому використання внутрішньолінійного підбору мало обмежений характер. Крім загальної тенденції, що пояснює прогресивну дію породотворного процесу, визначили окремі варіанти поєднуваності ліній, які відрізнялися за рівнем молочності та жирномолочності. Так, внутрішньолінійний підбір спорідненої групи Цирруса, лінії Ладного сприяв підвищенню вмісту жиру в молоці у корів-первісток у I, II i III етапах, а ліній Елевейшна, Старбака, Чіфра - рівня надою у IV i V emanaх виведення і консолідації породи. Найефеективнішим методом підвищення мінливості селекиійних ознак молочної худоби є міжлінійне розведення. У породотворному процесі інтенсивно використовувався міжлінійний підбір, результати якого постійно аналізувалися для виявлення кращих поєднань ліній та їх послідуючого повторення. Встановлено, що в перші три етапи (I-III) виведення української червоної молочної породи переважав підбір ліній червоної степової (материнська) і споріднених груп англерської (батьківська) порід. Більшість таких кросів характеризувалися середнім надоєм від 3087 кә (Коломбо × Візита) до 4839 кә (Корбітиа х Ладного) і підвищеним вмістом жиру в молоці - 4,07 \% (Коломбо × Ладного) і 4,41% (Цирруса × Бриза). Особливістю III, IV, $V$ етапів виведення породи було залучення до породотворного процесу продовжувачів ліній голштинської породи. Це сприяло підвищенню надою (5082 кг), але одночасно зумовило зниження вмісту жиру в молоці (3,72 \%), зокрема при підборі бугаїв-плідників лінії Вісконсіна до корів спорідненої групи Корбітиа. Міжлінійний підбір впливає на продуктивні та відтворювальні ознаки української червоної молочної породи. У результаті використання для підбору споріднених груп англерської породи (I-III етапи) відбулося підвищення жирномолочності у тварин, а залучення до породотворного процесу ліній голштинської породи сприяло підвищенню молочності (IV-V етапи).
\end{abstract}

Ключові слова: українська червона молочна порода, лінійне розведення, молочна продуктивність, відтворювальна здатність.

DOI: https://doi.org/10.32845/bsnau.lvst.2019.4.5

Динамізм порід великої рогатої худоби підтримується завдяки наявності в них достатньої кількості структурних формувань. Якщо породу узагальнено розглядати як систему, то процес перетворення в ній проводити досить складно, або навіть і неможливо, тому її слід розподілити на менші структурні складові. У них можна виявити зміни, які відбуваються в суміжних поколіннях. Це дозволяє забезпечити бажані зміни в таких структурах і з часом, за сприятливих умов, розповсюдити їх на всю породу [1].

Лінії $€$ основними структурними елементами, з яких складається порода. В них проводиться племінна робота 3 покращення цінних якостей, накопичення в сукупному генотипі лінії адитивних генів високої продуктивності або при використанні кросів - неадитивного генетичного ефректу [2]. Порода в цілому може прогресувати при наявності достатньої кількості ліній [3]. Дослідженнями І.В. Йовенко [4] доведено, що розведення за лініями є одним із основних прийомів удосконалення порід.

Вісник Сумського національного аграрного університету Серія «Тваринництво», випуск 4 (39), 2019
У молочному скотарстві породополіпшувальний процес відбувається за принципом відкритої популяції, оскільки в стадах великої рогатої худоби використовуються різноманітні лінії голштинської породи.

В лінійному розведенні молочної худоби встановлено невисокі темпи генетичного прогресу за селекційними ознаками $[5,6]$. Про неприйнятність лінійного розведення великої рогатої худоби також повідомляє М.Й. Чехівський [7], вказуючи при цьому низку причин неефективного його використання.

Іншої думки дотримуються Ю. Полупан та ін. [8], оскільки зазначають необхідність постійної перевірки ефективності поєднання ліній та споріднених груп для подальшого удосконалення української червоної молочної породи, що дозволить використати вдалі поєднання і не повторювати малоефективні.

Про необхідність та доцільність постійного моніторингу поєднання ліній у процесі селекції української червоно- 
рябої молочної породи повідомляють В.В. Костюк [9], І.А. Гальчинська [10]; червоної молочної худоби - Т.П. Коваль [12], Т.В. Підпала [11], С.І. Гнатюк [13], оскільки повторне застосування найбільш вдалих варіантів та відмова від малоесективних сприятиме нарощуванню генетичного потенціалу високої молочної продуктивності.

Встановлена міжлінійна диференціація за показниками довічного використання дозволяє вибрати кращі варіанти генеалогічних формувань для підбору, що в свою чергу сприятиме як поліпшенню окремих селекційних груп, так і породи в цілому [14].

Мета досліджень. У молочному скотарстві велику увагу приділяють роботі з лініями, що має велике значення у породоутворювальному процесі. Тому, доцільно проаналізувати ефективність використання лінійного розведення на різних етапах виведення та консолідації української червоної молочної породи великої рогатої худоби. Зазначена мета виконувалася через такі завдання: оцінити молочну продуктивність за внутрішньолінійного та міжлінійного підбору; проаналізувати відтворювальну здатність корів при лінійному розведенні.

Матеріали і методи досліджень. Для виконання дослідження використали дані племінного обліку стада великої рогатої худоби української червоної молочної породи племзаводу ПОК «Зоря» Херсонської (період виведення української червоної молочної породи) і ТОВ «Колос 2011»
Миколаївської (період консолідації української червоної молочної породи) областей. В даних господарствах здійснювалися породоперетворювальні процеси в популяції червоної степової худоби із залученням генофонду англерської, червоної датської та голштинської порід. Період виведення та консолідації породи умовно розподілили на п'ять етапів, з яких було відібрано для ретроспективного аналізу внутрішньолінійного та міжлінійного підбору корів-первісток. Для опрацювання отриманих даних застосовували методи варіаційної статистки $[15,16]$. Біометрична обробка матеріалів досліджень здійснювалася з використанням програмного забезпечення Microsoft Excel.

Результати досліджень/ У результаті лінійного розведення здійснюється селекція в менш чисельних групах молочної худоби і через видатних бугаїв-поліпшувачів прискорюється процес передачі цінної спадковості та отримання тварин з високою продуктивністю. Дотримання принципів лінійного розведення забезпечує також уникнення стихійного інбридингу та формування структури нової породи.

Оскільки виведення української червоної молочної породи здійснювалося із залученням генофонду англерської, червоної датської та голштинської порід, то й використання внутрішньолінійного підбору мало обмежений характер (табл. 1).

\section{Молочна продуктивність корів-первісток української червоної}

Таблиця 1

молочної породи при внутрішньолінійному підборі, $\bar{X} \pm S x$ \begin{tabular}{|c|c|c|c|c|c|}
\hline Лінія, споріднена група & $\mathrm{n}$ & Надій за всю лактацію, кг & Надій за 305 днів лактації, кг & Вміст жиру в молоці, \% & Кількість молочного жиру, кг \\
\hline
\end{tabular}

\begin{tabular}{|c|c|c|c|c|c|}
\hline \multicolumn{6}{|c|}{ І етап } \\
\hline Казбека & 10 & $3654 \pm 251,1$ & $3528 \pm 195,6$ & $3,89 \pm 0,090$ & $139,6 \pm 9,21$ \\
\hline Ладного & 12 & $3874 \pm 249,9$ & $3670 \pm 198,0$ & $3,93 \pm 0,065$ & $144,6 \pm 8,31$ \\
\hline Цирруса & 16 & $4102 \pm 235,9$ & $3938 \pm 192,4$ & $4,08 \pm 0,129$ & $159,5 \pm 7,17$ \\
\hline \multicolumn{6}{|c|}{ II етап } \\
\hline Казбека & 8 & $4438 \pm 228,0$ & $4201 \pm 166,2$ & $3,85 \pm 0,072$ & $160,9 \pm 5,87$ \\
\hline Ладного & 11 & $4822 \pm 204,5$ & $4510 \pm 204,7$ & $4,01 \pm 0,052$ & $179,2 \pm 7,44$ \\
\hline Цирруса & 34 & $4240 \pm 122,1$ & $4107 \pm 113,2$ & $4,08 \pm 0,056$ & $167,6 \pm 4,19$ \\
\hline Фрема & 1 & 4755 & 4755 & 3,86 & 183,8 \\
\hline \multicolumn{6}{|c|}{ III етап } \\
\hline Ладного & 3 & $4014 \pm 978,1$ & $3891 \pm 982,3$ & $4,09 \pm 0,158$ & $156,6 \pm 35,69$ \\
\hline Фрема & 3 & $4029 \pm 500,1$ & $3912 \pm 503,7$ & $3,86 \pm 0,097$ & $151,7 \pm 21,39$ \\
\hline \multicolumn{6}{|c|}{ IV етап } \\
\hline Елевейшна & 4 & $7624 \pm 1840,0$ & $5863 \pm 389,3$ & $3,75 \pm 0,026$ & $219,5 \pm 14,38$ \\
\hline Рігел Реда & 12 & $5439 \pm 468,6$ & $4846 \pm 308,6$ & $3,83 \pm 0,040$ & $186,0 \pm 12,61$ \\
\hline Старбака & 4 & $7649 \pm 598,6$ & $6810 \pm 417,9$ & $3,88 \pm 0,023$ & $264,2 \pm 16,17$ \\
\hline Фрема & 8 & $6230 \pm 730,1$ & $5451 \pm 528,2$ & $3,74 \pm 0,042$ & $205,5 \pm 21,82$ \\
\hline Цирруса & 12 & $5306 \pm 357,3$ & $4956 \pm 325,3$ & $3,88 \pm 0,034$ & $192,4 \pm 12,47$ \\
\hline \multicolumn{6}{|c|}{ V етап } \\
\hline Старбака & 25 & $8486 \pm 443,1$ & $7689 \pm 297,8$ & $3,84 \pm 0,025$ & $293,0 \pm 11,33$ \\
\hline पicpa & 9 & $9724 \pm 724,1$ & $9086 \pm 558,3$ & $3,85 \pm 0,049$ & $349,4 \pm 20,24$ \\
\hline
\end{tabular}

Незважаючи на малочисельність тварин, що отримані в результаті внутрішньолінійного підбору, встановили підвищення молочної продуктивності корів з I по V етап. Крім загальної тенденції, що пояснює прогресивну дію породотворного процесу, визначили окремі варіанти поєднуваності ліній, які відрізнялися за рівнем молочності та жирномолочності. Так, внутрішньолінійний підбір спорідненої групи Цирруса, лінії Ладного сприяв підвищенню вмісту жиру в молоці у корів-первісток у I, II і III етапах, а ліній Елевейшна, Старбака, Чіфа - рівня надою у IV i V етапах виведення і консо- лідації породи. Відмінності також встановлені й за ознаками, які характеризували відтворювальні здатності тварин (табл. 2).

Подовженою тривалістю лактаційного, сервіс- і міжотельного періодів характеризувалися корови-первістки, що отриманні в результаті внутрішньолінійного підбору в лінії Елевейшна (IV етап), вони мали і найнижчий показник коефіцієнта відтворювальної здатності $(0,87)$.

Отже, в різні етапи виведення і консолідації української червоної молочної породи застосування внутрішньолі-

Вісник Сумського національного аграрного університету Серія «Тваринництво», випуск 4 (39), 2019 
нійного підбору зумовило підвищенню молочної продуктивності у тварин. Разом з тим, підбір ліній в окремих поєднаннях (спорідненої групи Цирруса, лінії Ладного) сприяв формуванню у тварин високої жирномолочності, а в інших (лінії Елевейшна, Старбака, Чіфа) - високої молочності.

Найефективнішим методом підвищення мінливості селекційних ознак молочної худоби є міжлінійне розведення. Виявлення вдалих поєднань ліній та використання внутрішньопородного гетерозису значно впливає на підвищення продуктивності, біологічної повноцінності тварин і виникнення у них нових, більш цінних властивостей [17].

Таблиця 2

Відтворювальна здатність корів-первісток української червоної молочної породи при внутрішньолінійному підборі, $\bar{X} \pm S x$

\begin{tabular}{|c|c|c|c|c|c|}
\hline Лінія & $\mathrm{n}$ & Дні лактації & Сервіс-період & МОП & KB3 \\
\hline \multicolumn{6}{|c|}{ І етап } \\
\hline Казбека & 10 & $291,9 \pm 13,91$ & $74,2 \pm 13,03$ & $356,2 \pm 12,65$ & $1,04 \pm 0,035$ \\
\hline Ладного & 12 & $319,4 \pm 12,69$ & $104,2 \pm 11,93$ & $377,1 \pm 15,47$ & $0,99 \pm 0,043$ \\
\hline Цирруса & 16 & $304,9 \pm 13,16$ & $97,0 \pm 14,31$ & $375,4 \pm 14,76$ & $0,99 \pm 0,037$ \\
\hline \multicolumn{6}{|c|}{ II етап } \\
\hline Казбека & 8 & $317,6 \pm 12,14$ & $101,6 \pm 12,43$ & $384,1 \pm 12,70$ & $0,96 \pm 0,034$ \\
\hline Ладного & 11 & $329,6 \pm 23,04$ & $123,4 \pm 25,49$ & $399,0 \pm 30,20$ & $0,98 \pm 0,084$ \\
\hline Цирруса & 34 & $303,6 \pm 5,59$ & $82,7 \pm 6,01$ & $359,9 \pm 5,96$ & $1,02 \pm 0,017$ \\
\hline Фрема & 1 & 307,0 & 39,0 & 473,0 & 0,77 \\
\hline \multicolumn{6}{|c|}{ III етап } \\
\hline Ладного & 3 & $295,0 \pm 35,22$ & $85,0 \pm 41,20$ & $376,7 \pm 33,20$ & $0,98 \pm 0,080$ \\
\hline Фрема & 3 & $318,7 \pm 23,81$ & $100,7 \pm 15,4$ & $384,0 \pm 17,01$ & $0,95 \pm 0,043$ \\
\hline \multicolumn{6}{|c|}{ IV етап } \\
\hline Елевейшна & 4 & $407,0 \pm 88,28$ & $182,2 \pm 87,85$ & $457,0 \pm 88,61$ & $0,87 \pm 0,123$ \\
\hline Рігел Реда & 12 & $325,7 \pm 25,71$ & $106,8 \pm 27,49$ & $381,7 \pm 28,14$ & $1,01 \pm 0,061$ \\
\hline Старбака & 4 & $349,2 \pm 46,43$ & $120,0 \pm 82,3$ & $403,0 \pm 50,11$ & $0,94 \pm 0,101$ \\
\hline Фрема & 8 & $360,9 \pm 44,19$ & $137,0 \pm 48,57$ & $417,8 \pm 48,04$ & $0,93 \pm 0,072$ \\
\hline Цирруса & 12 & $336,9 \pm 14,36$ & $125,1 \pm 20,91$ & $404,3 \pm 20,89$ & $0,93 \pm 0,044$ \\
\hline \multicolumn{6}{|c|}{ V етап } \\
\hline Старбака & 25 & $338,6 \pm 16,66$ & $99,8 \pm 14,78$ & $388,4 \pm 16,19$ & $0,97 \pm 0,030$ \\
\hline Чiфа & 9 & $330,3 \pm 22,79$ & $110,4 \pm 28,49$ & $389,3 \pm 28,77$ & $0,97 \pm 0,050$ \\
\hline
\end{tabular}

У породотворному процесі інтенсивно використовувався міжлінійний підбір, результати якого постійно аналізувалися для виявлення кращих поєднань ліній та їх послідуючого повторення. Порівняльним аналізом встановлено, що в перші три етапи (I-III) виведення української червоної молочної породи переважав підбір ліній червоної степової (материнська) і споріднених груп англерської (батьківська) порід (табл. 3). Більшість кросів характеризувалися середнім надоєм від 3087 кг (Коломбо × Візита) до 4839 кг (Корбітца × Ладного) і підвищеним вмістом жиру в молоці - 4,07 \% (Коломбо × Ладного) і 4,41 \% (Цирруса × Бриза). Особливістю III, IV, V етапів виведення породи було залучення до породотворного процесу продовжувачів ліній голштинської породи. Це сприяло підвищенню надою (5082 кг), але одночасно зумовило зниження вмісту жиру в молоці (3,72 \%), зокрема при підборі бугаїв-плідників лінії Вісконсіна до корів спорідненої групи Корбітца.

Найвищою молочністю у IV етапі характеризувалися корови від поєднань ліній: Астронавта × Фрема (10338 кг), Хановер Реда × Валіанта (11049 кг), а в V етапі - Старбака × Елевейшна (12942 кг), Чіфа × Елевейшна (13203 кг). Вказані варіанти кросів ефективні не лише за величиною надою, а й за вмістом жиру в молоці, оскільки значення даної ознаки відповідає породним параметрам [18], за винятком кросу Хановер Реда × Валіанта (вміст жиру в молоці 3,74\%).

Були отримані й інші поєднання ліній та споріднених груп, які також відрізнялися за рівнем розвитку основних ознак молочної продуктивності. Менш результативними у перші етапи виведення породи були поєднання ліній червоної степової породи (кроси: Бриза × Візита, Ладного × Казбека), а також при реципрокному підборі, тобто батьківські лінії червоної степової породи і материнські - споріднені групи англерської породи (крос Візита × Коломбо). Встановлено, що міжлінійний підбір сприяв підвищенню жирномолочності завдяки використанню продовжувачів споріднених груп англерської породи.

У подальшому (IV i V етапи) за різних варіантів міжлінійного підбору спостерігається значне підвищення величина надою, але такий підбір спричиняє у окремих поєднаннях до зниження жирномолочності, зокрема кроси: Фрема $\mathrm{x}$ Хановер Реда, Фрема × Цируса, Старбака × Чіфа, Елевейшна $\times$ Старбака та інші.

Враховуючи важливість відтворення молочної худоби, оцінили досліджуване поголів'я корів від міжлінійного підбору за ознаками відтворювальної здатності. Порівняльним аналізом встановлено, що у період І-ІІІ етапів виведення української червоної молочної породи тварини характеризувалися оптимальними значеннями коефіцієнта відтворювальної здатності, за винятком кросів: Казбека × Коломбо $(0,88)$ і М. Чіфтейна $\times$ Фрема $(0,86)$. У IV i V етапи спостерігається погіршення відтворювальної здатності корів за міжлінійного підбору в таких лінійних поєднаннях, як Астронавта $\times$ Фрема, Маршала $\times$ Белла, Рігел Реда $\times$ Фрема, Старбака $\times$ Цирруса, Фрема $\times$ Цирруса, Чіфра $\times$ Елевейшна. У корів, що отриманні від цих кросів середній показник коефіцієнта відтворювальної знаходився в межах 0,69-0,77. 
Молочна продуктивність корів первісток української червоної

Таблиця 3 молочної породи при міжлінійному підборі, $\bar{X} \pm S x$

\begin{tabular}{|c|c|c|c|c|c|c|}
\hline \multicolumn{2}{|c|}{ Лінія, споріднена група } & \multirow{2}{*}{$\mathrm{n}$} & \multirow{2}{*}{$\begin{array}{l}\text { Надій за всю } \\
\text { лактацію, кг }\end{array}$} & \multirow{2}{*}{$\begin{array}{c}\text { Надій за } 305 \text { днів } \\
\text { лактації, кг }\end{array}$} & \multirow{2}{*}{$\begin{array}{c}\text { Вміст жиру в } \\
\text { молоці, \% }\end{array}$} & \multirow{2}{*}{$\begin{array}{c}\text { Кількість молочного } \\
\text { жиру, кг }\end{array}$} \\
\hline батька & матері & & & & & \\
\hline \multicolumn{7}{|c|}{ І етап } \\
\hline \multirow{3}{*}{ Коломбо } & Візита & 9 & $3087 \pm 146,84$ & $3053 \pm 133,2$ & $3,90 \pm 0,060$ & $119,0 \pm 5,32$ \\
\hline & Казбека & 8 & $3562 \pm 271,5$ & $3444 \pm 236,2$ & $3,89 \pm 0,058$ & $133,1 \pm 8,69$ \\
\hline & Ладного & 20 & $3443 \pm 153,8$ & $3381 \pm 137,5$ & $4,07 \pm 0,060$ & $136,0 \pm 5,62$ \\
\hline \multirow{3}{*}{ Цирруса } & Бриза & 9 & $3837 \pm 329,8$ & $3789 \pm 317,5$ & $3,93 \pm 0,080$ & $148,9 \pm 12,27$ \\
\hline & Казбека & 17 & $3793 \pm 151,3$ & $3753 \pm 141,2$ & $3,93 \pm 0,095$ & $148,9 \pm 6,09$ \\
\hline & Ладного & 25 & $3963 \pm 114,4$ & $3803 \pm 71,8$ & $4,09 \pm 0,060$ & $156,2 \pm 3,79$ \\
\hline \multicolumn{7}{|c|}{ II етап } \\
\hline \multirow{2}{*}{ Фрема } & Ладного & 10 & $4131 \pm 131,5$ & $4128 \pm 130,7$ & $4,11 \pm 0,079$ & $169,4 \pm 3,69$ \\
\hline & Цирруса & 11 & $4328 \pm 172,1$ & $4255 \pm 158,4$ & $4,11 \pm 0,101$ & $174,2 \pm 6,42$ \\
\hline \multirow{3}{*}{ Цирруса } & Бриза & 7 & $4508 \pm 356,6$ & $4201 \pm 211,9$ & $4,41 \pm 0,121$ & $185,8 \pm 11,27$ \\
\hline & Казбека & 9 & $4208 \pm 206,3$ & $4132 \pm 163,3$ & $4,09 \pm 0,121$ & $169,0 \pm 7,83$ \\
\hline & Ладного & 25 & $3925 \pm 116,0$ & $3837 \pm 98,2$ & $4,15 \pm 0,051$ & $161,4 \pm 4,40$ \\
\hline \multicolumn{7}{|c|}{ III етап } \\
\hline \multirow{2}{*}{ Корбітца } & Казбека & 3 & $4387 \pm 205,5$ & $4387 \pm 205,5$ & $3,92 \pm 0,042$ & $171,8 \pm 7,97$ \\
\hline & Ладного & 4 & $4839 \pm 427,7$ & $4699 \pm 439,5$ & $3,90 \pm 0,069$ & $182,2 \pm 12,96$ \\
\hline Фрема & Сета & 8 & $3938 \pm 355,5$ & $3764 \pm 345,7$ & $3,60 \pm 0,045$ & $136,1 \pm 13,40$ \\
\hline \multirow{4}{*}{ Вісконсіна } & Казбека & 6 & $4175 \pm 241,3$ & $4142 \pm 239,6$ & $3,86 \pm 0,058$ & $159,5 \pm 7,24$ \\
\hline & Корбітца & 4 & $5082 \pm 159,0$ & $4904 \pm 125,1$ & $3,72 \pm 0,064$ & $182,6 \pm 4,13$ \\
\hline & Фрема & 6 & $4722 \pm 386,6$ & $4609 \pm 339,3$ & $3,79 \pm 0,035$ & $174,7 \pm 12,66$ \\
\hline & Ладного & 12 & $4258 \pm 212,8$ & $4091 \pm 191,3$ & $3,80 \pm 0,027$ & $162,2 \pm 6,48$ \\
\hline \multicolumn{7}{|c|}{ IV етап } \\
\hline \multirow{2}{*}{ Астронавта } & Фрема & 6 & $10338 \pm 1737,8$ & $6800 \pm 345,2$ & $3,85 \pm 0,014$ & $262,0 \pm 13,57$ \\
\hline & Хановер Реда & 6 & $7668 \pm 613,2$ & $6988 \pm 449,8$ & $3,85 \pm 0,052$ & $269,0 \pm 18,54$ \\
\hline \multirow{3}{*}{ Ханновер Реда } & Фрема & 12 & $6488 \pm 582,2$ & $5994 \pm 479,5$ & $3,73 \pm 0,026$ & $223,6 \pm 18,14$ \\
\hline & Цирруса & 10 & $6519 \pm 1044,1$ & $5379 \pm 628,6$ & $3,71 \pm 0,024$ & $199,3 \pm 23,15$ \\
\hline & Валіанта & 4 & $11049 \pm 2495,3$ & $8223 \pm 807,1$ & $3,74 \pm 0,059$ & $307,8 \pm 32,63$ \\
\hline \multicolumn{7}{|c|}{ V етап } \\
\hline \multirow[t]{3}{*}{ Елевейшна } & Старбака & 17 & $10873 \pm 535,3$ & $9480 \pm 352,6$ & $3,78 \pm 0,023$ & $356,5 \pm 11,81$ \\
\hline & Хановер Реда & 7 & $12096 \pm 2238,9$ & $8508 \pm 536,9$ & $3,81 \pm 0,046$ & $324,2 \pm 19,76$ \\
\hline & पipa & 4 & $11831 \pm 2457,8$ & $9349 \pm 788,1$ & $3,87 \pm 0,031$ & $362,0 \pm 31,25$ \\
\hline \multirow[t]{4}{*}{ Старбака } & Хановер Реда & 20 & $10420 \pm 542,3$ & $9241 \pm 356,8$ & $3,78 \pm 0,022$ & $349,1 \pm 13,62$ \\
\hline & Валіанта & 13 & $9348 \pm 869,5$ & $8298 \pm 622,0$ & $3,88 \pm 0,024$ & $320,8 \pm 23,24$ \\
\hline & Астронавта & 8 & $8901 \pm 835,8$ & $8349 \pm 473,0$ & $3,89 \pm 0,059$ & $322,7 \pm 15,31$ \\
\hline & Елевейшна & 6 & $12942 \pm 1968,6$ & $9399 \pm 566,1$ & $3,86 \pm 0,030$ & $361,5 \pm 20,01$ \\
\hline \multirow[t]{2}{*}{ Маршала } & Елевейшна & 6 & $11127 \pm 918,7$ & $9357 \pm 549,1$ & $3,84 \pm 0,023$ & $359,2 \pm 20,36$ \\
\hline & Старбака & 19 & $10449 \pm 602,8$ & $9138 \pm 298,7$ & $3,82 \pm 0,023$ & $348,9 \pm 11,41$ \\
\hline \multirow[t]{3}{*}{ Чiфpa } & Елевейшна & 7 & $13203 \pm 2663,5$ & $9237 \pm 782,0$ & $3,86 \pm 0,050$ & $355,3 \pm 28,13$ \\
\hline & Старбака & 26 & $7455 \pm 275,8$ & $7163 \pm 182,3$ & $3,95 \pm 0,058$ & $281,7 \pm 6,69$ \\
\hline & Хановер Реда & 14 & $7326 \pm 235,6$ & $7002 \pm 195,7$ & $4,05 \pm 0,085$ & $282,2 \pm 5,55$ \\
\hline
\end{tabular}

Таким чином, міжлінійний підбір впливає на продуктивні та відтворювальні ознаки української червоної молочної породи. У результаті використання для підбору споріднених груп англерської породи (I-ІІІ етапи) відбулося підвищення жирномолочності у тварин, а залучення до породотворного процесу ліній голштинської породи сприяло підвищенню молочності (IV-V етапи).

Висновки і перспективи подальших досліджень. Встановлено, що в різні етапи виведення і консолідації української червоної молочної породи застосування внутрішньолінійного підбору зумовило підвищенню молочної продуктивності у тварин. Підбір ліній в окремих поєднаннях (спорідненої групи Цирруса, лінії Ладного) сприяв фрорму- ванню у корів високої жирномолочності, а в інших (лінії Елевейшна, Старбака, Чіфа) - високої молочності. У результаті використання міжлінійного підбору споріднених груп англерської породи (I-ІІІ етапи) відбулося підвищення жирномолочності (Коломбо × Ладного - 4,07 \% і Цирруса $\times$ Бриза $-4,41 \%)$, а залучення до породотворного процесу (IV-V етапи) ліній голштинської породи сприяло підвищенню молочності (Астронавта × Фрема - 10338 кг; Хановер Реда х Валіанта - 11049 кг; Старбака × Елевейшна - 12942 кг; Чіфа × Елевейшна - 13203 кг). В подальшому передбачається дослідити ефрективність довічного використання корів за різних варіантів лінійного підбору.

\section{Список використаної літератури:}

1. Сметанин В.Т. Линейное разведение как метод структурирования и механизм сохранения внутрипопуляционной изменчивости в породах. Розведення і генетика тварин. 2005. Вип. 39, С. 189-189. 
2. Підпала Т.В. Методологічні підходи оцінки взаємодії «генотип-середовище» при селекції червоних порід худоби. Генетика і селекція в Україні на межі тисячоліть. К. : Логос, 2001. Т 4. С. 91-98.

3. Міжпородне схрещування в популяції молочної худоби. А.М. Дубін [та ін.] ; за ред. С. Ю. Рубана. К. : Науковий світ. 2009. $170 \mathrm{C}$.

4. Йовенко І.В. Розведення української чорно-рябої молочної худоби за лініями і родинами в системі великомасштабної селекції. Науково-технічний бюлетень Інституту тваринництва УААН. Харків. 2001. № 80, С. 57-58.

5. Йовенко І.В., Йовенко В.В. Особливості розведення за лініями при великомасштабній селекції. 2003. Вип. 35, С. 50 -

54.

6. Рудик І.А., Ставецька Р.В., Судика В.В., Ткач С.О. До проблеми розведення за лініями при великомасштабній селекції молочної худоби. Розведення і генетика тварин. 2005. Вип. 38, С. 110-116.

7. Чехівський М. Й. Про неприйнятність лінійного розведення великої рогатої худоби. Розведення і генетика тварин. 2005. Вип. 38, С. 116-118.

8. Полупан Ю., Коваль Т., Вороненко В. Поєднуваність ліній і споріднених груп червоної молочної худоби. Тваринництво України. 2003. № 11, С. 11- 14.

9. Костюк В.В. Екстер'єрні та продуктивні особливості молочної худоби різного походження : автореф. дис. на здобуття наук. ступеня канд. с.-г. наук : спец. 06.02.01 «Розведення та селекція тварин». с. Чубинське, 2010. 20 с.

10. Гальчинська І.А. Роль селекційно-генетичних фракторів у формуванні заводського стада української червоно-рябої молочної породи : автореф. дис. на здобуття наук. ступеня канд. с.-г. наук : спец. 06.02.01 «Розведення та селекція тварин». Київ - Чубинське, 2009. 19 с.

11. Підпала Т.В. Лінійне розведення в селекції червоної степової худоби. Таврійський науковий вісник. Херсон : Айлант. 1998. Вип. 8, С. 71-77.

12. Коваль Т.П. Поєднуваність ліній і споріднених груп червоної молочної худоби за показниками тривалості та ефрективності її довічного використання. Науковий вісник «Асканія-Нова». Нова Каховка : ЧП «ПИЕЛ». 2009. Вип. 2, С.66-72.

13. Гнатюк С.І. Оцінка ефективності формування внутрішньопородних типів української червоної молочної породи: автореф. дис. на здобуття наук. ступеня канд. с.-г. наук : спец. 06.02.01 «Розведення та селекція тварин». с. Чубинське Київської області, 2012. 20 с.

14. Гнатюк С.І., Хмельничий Л.М. Ефективність довічного використання корів української червоної молочної молочної породи залежно від внутрішньопородних типів та генеалогічних фрормувань. Технологія виробництва і переробки продукції тваринництва. 2010. Вип. 3 (72), С. 111-115.

15. Підпала Т.В., Войналович С.А., Назаренко В.Г., Герасименко В.В., Стріха Л.О., Цхвітава О.К. Селекція молочної худоби і свиней : навч. посіб. /; за ред. професора Т. В. Підпалої. Миколаїв : МНАУ, 2012. 297 с.

16. Крамаренко С.С., Луговий С.І., Лихач А.В., Крамаренко О.С. Аналіз біометричних даних у розведенні та селекції тварин. Миколаїв, МНАУ. 2019. 211 с.

17. Підпала Т.В. Генезис породного перетворення в популяції червоної степової худоби : монографія. Миколаїв : МДАУ, 2005. 312 c.

18. Програма селекції української червоної молочної породи великої рогатої худоби на 2003-2012 роки. Д. М. Микитюк [та ін.].; за ред. Ю. П. Полупана і В. П. Бурката. К., 2004. 216 с.

\section{References:}

1. Smetanyn, V. T., 2005. Lyneinoe razvedenye kak metod strukturyrovanyia y mekhanyzm sokhranenyia vnutrypopuliatsyonnoi yzmenchyvosty $v$ porodakh [Linear breeding as a method of structuring and mechanism of preservation of intra-population variability in breeds]. Rozvedennia i henetyka tvaryn, issue 39, pp. 189-189.

2. Pidpala, T.V., 2001. Metodolohichni pidkhody otsinky vzaiemodii «henotyp-seredovyshche» pry selektsii chervonykh porid khudoby [Methodological approaches of genotype-environment interaction estimation in breeding of red cattle breeds]. Henetyka $i$ selektsiia v Ukraini na mezhi tysiacholit, vol. 4, pp. 91-98.

3. Dubin, A.M., Afanasenko, V. Yu., Kovalchuk, A.I. and Kudlai, I.M., 2009. Mizhporodne skhreshchuvannia v populiatsii molochnoi khudoby [Interspecific crossing in dairy cattle populations]. Kyiv: Naukovyi svit.

4. Yovenko, I.V., 2001. Rozvedennia ukrainskoi chorno-riaboi molochnoi khudoby za liniiamy i rodynamy v systemi velykomasshtabnoi selektsii [Breeding of Ukrainian black-and-white dairy cattle by lines and families in the system of large-scale breeding]. Naukovo-tekhnichnyi biuleten Instytutu tvarynnytstva UAAN, issue 80, pp. 57-58.

5. Yovenko, I.V. and Yovenko, V.V., 2003. Osoblyvosti rozvedennia za liniiamy pry velykomasshtabnii selektsii [Features of line breeding in large-scale breeding]. Rozvedennia i henetyka tvaryn, issue 35, pp. 50-54.

6. Rudyk, I.A., Stavetska P.B., Sudyka V.V., Tkach S.O., 2005 Do problemy rozvedennia za liniiamy pry velykomasshtabnii selektsii molochnoi khudoby [On the problem of line breeding in large-scale breeding of dairy cattle]. Rozvedennia $i$ henetyka tvaryn, issue. 38 , pp. 110-116.

7. Chekhivskyi, M. Y., 2005. Pro nepryiniatnist liniinoho rozvedennia velykoi rohatoi khudoby [On the inadmissibility of linear breeding of cattle]. Rozvedennia i henetyka tvaryn, issue, 38, pp. 116-118.

8. Polupan, Yu., Koval, T., and Voronenko, V., 2003. Poiednuvanist linii ta sporidnenykh hrup chervonoi molochnoi khudoby [The compatibility of lines and related groups of red dairy cattle]. Tvarynnytstvo Ukrainy, issue 11, pp. 11-14.

9. Kostiuk, V. V., 2010. Eksterierni ta produktyvni osoblyvosti molochnoi khudoby riznoho pokhodzhennia. Abstract of Ph.D. s. Chubynske. Rozvedennia ta selektsiia tvaryn. 
10. Halchynska, I.A., 2009. Rol selektsiino-henetychnykh faktoriv u formuvanni zavodskoho stada ukrainskoi chervono-riaboi molochnoi porody. Abstract of Ph.D. Kyiv-Chubynske. Rozvedennia ta selektsiia tvaryn.

11. Pidpala, T.V., 1998. Liniine rozvedennia v selektsii chervonoi stepovoi khudoby [Linear breeding in breeding of red steppe cattle]. Tavriiskyi naukovyi visnyk, issue 8, pp. 71-77.

12. Koval, T.P., 2009. Poiednuvanist linii i sporidnenykh hrup chervonoi molochnoi khudoby za pokaznykamy tryvalosti ta efektyvnosti yii dovichnoho vykorystannia [Compatibility of lines and related groups of red dairy cattle by duration and efficiency of their lifelong use]. Naukovyi visnyk «Askaniia-Nova», issue 2, pp. 66-72.

13. Hnatiuk, S.I., 2012. Otsinka efektyvnosti formuvannia vnutrishnoporodnykh typiv ukrainskoi chervonoi molochnoi porody. Abstract of Ph.D. Kyiv-Chubynske. Rozvedennia ta selektsiia tvaryn.

14. Hnatiuk, S.I., and Khmelnychyi, L.M., 2010. Efektyvnist dovichnoho vykorystannia koriv ukrainskoi chervonoi molochnoi molochnoi porody zalezhno vid vnutrishnoporodnykh typiv ta henealohichnykh formuvan [Efficiency of life-long use of cows of Ukrainian red milk dairy breed depending on inbred types and genealogical formations]. Tekhnolohiia vyrobnytstva $i$ pererobky produktsii tvarynnytstva, issue 3 (72), pp. 111-115.

15. Pidpala, T.V., Voinalovych, S.A., Nazarenko, V. H., Herasymenko, V.V., Strikha, L.O. and Tskhvitava, O. K., 2012. Selektsiia molochnoi khudoby i svynei [Breeding of dairy cattle and pigs]. Mykolaiv : MNAU.

16. Kramarenko, S.S., Luhovyi, S.I., Lykhach, A.V. and Kramarenko, O.S., 2019. Analiz biometrychnykh danykh u rozvedenni ta selektsii tvaryn [Analysis of biometric data in breeding and breeding animals]. Mykolaiv: MNAU.

17. Pidpala, T.V., 2005 Henezys porodnoho peretvorennia v populiatsii chervonoi stepovoi khudoby [Genesis of breed transformation in the population of red steppe cattle]. Mykolaiv: MDAU.

18. Mykytiuk, D.M., Polupana, Yu.P., and Burkata, V.P., 2004. Prohrama selektsii ukrainskoi chervonoi molochnoi porody velykoi rohatoi khudoby na 2003-2012 roky [Breeding program for Ukrainian Red Dairy Breed of cattle for 2003-2012]. Kyiv.

Pidpala T.V.,

Shevchuk N.P.

Diversion by lines in different stages of exclusion and consolidation of Ukrainian Red Cattle Breed

The breeding process of line breeding are of great importance in, so it is advisable to analyze at different stages of removal and consolidation of the Ukrainian red dairy breed. Common zootechnical methods (individual accounting of dairy productivity), laboratory (determination of quality composition of milk), retrospective analysis (indicators for the whole period of use of animals), variational-statistical method (determination of parameters of traits) were used to perform the study. The removal of the Ukrainian red dairy breed was carried out with the involvement of the gene pool of Angler, Red Danish and Holstein breeds, and the use of inline selection was of limited nature. In addition to the general trend, which explains the progressive effect of the breeding process, identified some variants of line compatibility, which differed in milk and fat content. Thus, the in-line selection of the related group of Cirrus, the Ladny line contributed to the increase of fat content in milk of first-born cows in stages I, II and III, and the Elevation, Starbuck, Chifa lines - the level of milk yield in the IV and V stages of breeding and consolidation. The most effective method of increasing the variability of breeding characteristics of dairy cattle is interlinear breeding. Intermittent selection was intensively used in the breeding process, the results of which were constantly analyzed to identify the best line combinations and their subsequent repetition. It was established that in the first three stages (I-III) of Ukrainian red dairy breed removal the selection of lines of red steppe (maternal) and related groups of angler (parent) breeds prevailed. Most of these crosses were characterized by an average milk yield of $3087 \mathrm{~kg}$ (Colombo $\times$ Visit) to $4839 \mathrm{~kg}$ (Corbiza $\times$ Ladny) and high fat content in milk $-4.07 \%$ (Colombo $\times$ Ladny) and $4.41 \%$ (Cirrus $\times$ Breeze). The peculiarity of the III, IV, V stages of breeding was the involvement of extensions of Holstein breed lines in the breeding process. This contributed to an increase in milk yield (5082 kg), but at the same time led to a decrease in fat content in milk (3.72\%), in particular when selecting the Wisconsin lineage boogers for cows of the related Corbiza group. Interlinear selection affects the productive and reproductive features of the Ukrainian red dairy breed. As a result of the use for the selection of related groups of Angler breed (I-III stages), there was an increase in milk fat in animals, and involvement in the breeding process of lines of the Holstein breed contributed to the increase of milk yield (IV-V stages).

Key words: the Ukrainian Red Dairy Breed, line breeding, milk productivity, reproductive ability.

Дата надходження до редакції: 25.10.2019 р. 